\title{
Reasserting a Prehistoric Tragedy of the Commons: Reply to Lyman
}

\author{
TERRY L. JONES \\ Department of Anthropology, University of California, Davis, California 95616 \\ AND \\ WILLAm R. HILDEBRANDT \\ Far Western Authropolngicul Resenrch Gromp, Davis, California 95617
}

\begin{abstract}
R. Lee Lyman has challenged our assertion that prehistoric hunting of marine mammals along the west coast of North America approximated a prehistoric tragedy of the commons in which highly ranked migratory sea lions and fur seals were reduced by overexploitation, necessitating pursuit of smaller, more elusive harbor seals and sea otters late in time. In response, we review alternative theoretical perspectives, rebut Lyman's characterization of marine mammal reproductive behaviors, reanalyze seal and sea lion NISP data from the California and Oregon coasts, and reinterpret three regional prehistories. Because migratory pinnipeds need to breed on land, are vuinerable to terrestrial predation when congregated in breeding colonies, and employ migration corridors thousands of kilometers in length, they were susceptible to overexploitation. In areas where rookeries persisted on remote islands and offshore rocks, sophisticated weaponry and watercraft were developed to facilitate pursuit of $\mathrm{dwindling}$ populations and more elusive taxa as part of intensive, socially complex maritime economies.
\end{abstract}

The evolution of marine mammal hunting strategies and their association with complex, non-egalitarian hunter-gatherer cultures of the western North American coast are issues deserving continued analysis and debate. R. Lee Lyman has done this topic a service in his challenge to our recent proposals concerning prehistoric overexploitation of Northeastern Pacific sea mammals. Our original model was carefully conceived to articulate human optimal economic behavior, population growth and intensification, technological change, and sea mammal reproductive behavior and population ecology. In its support we summarized the majority of available zooarchaeological data from the California and Oregon coasts, including 16,123 large mammal bone identifications from 41 sites. We also reviewed seal and sea lion breeding behaviors and population biology, and ethnographic and historic accounts of seal and sea lion hunting. At the time of our 1992 paper we believed that only models which integrate all of these lines of evidence have the potential to successfully characterize the complex coevolution of marine mammal hunting strategies and coastal hunter-gatherer culture. We still believe this to be the case.

We consider the prehistory of marine mammal acquisition in western North America as a classic Irasedy of the commons, in which pinniped populations were overexploited during the course of thousands of years of pursuit by humans. Initially available in large numbers in mainland rookeries, fur seals and sea lions were pursued along the entire length of the California and Oregon coasts. Through time, exploitation of the easily accessible mainland breeding sites caused a decline in populations, a disappearance of these rookeries, and an increased reliance on smaller more elusive taxa (i.e., harbor seals and sea otter) that did not require terrestrial rookeries for reproduction. Pursuit technology gradually increased in sophistication as 
human hunters were forced to pursue their prey in less accessible offshore contexts.

Lyman's critique of our position covers a wide range of topics including the longterm accuracy of historically recorded pinniped and sea otter behavior, the viability of optimal foraging theory in the context of marine mammal hunting, and the adequacy of the archaeofaunal data summoned to evaluate our model. Our response covers a similar range of topics, beginning with a review of four theoretical perspectives currently applied to maritime prehistory in California and Oregon, followed by a detailed rebuttal to Lyman's characterization of marine mammal reproductive behaviors, a reanalysis of the archaeological evidence with greater emphasis on the environmental contexts of these finds, and a reinterpretation of three key regional prehistories which may reflect the recolonization of certain habitats under conditions of reduced predatory stress.

\section{ALTERNATIVE APPROACHES TO THE MARITIME PREHISTORY OF CALIFORNIA AND OREGON}

Our original paper dealing with the issue of marine mammal hunting adaptations (Hildebrandt and Jones 1992) was not only a response to Lyman's (1989) criticism of Hildebrandt's (1981, 1984a, 1984b) work, but was also designed to confront three alternative characterizations of the prehistory of California and Oregon: cultural evolutionary/migration models, a sea temperature model, and a neo-Marxist model. To these we can now add a fourth: a resource management model recently proposed by Lyman (1991b, this volume). In order to evaluate our findings within the larger interpretive context created by these studies, the following discussion provides a brief summary of the range of causative factors thought to have influenced the adaptive changes observed in the archaeological record.

\section{Cultural Evolution/Migration}

Although the era of its theoretical domination has long passed, cultural evolutionary concepts still underlie many regional cultural chronologies and have influenced perceptions of prehistoric marine resource exploitation. Interpreted within this framework, technological innovations are perceived as discoveries that allow for improved exploitation of previously overlooked or inaccessible resources. Intimately related to cultural evolution are models of migration and/or diffusion. Referred to by Lyman (1991a:73) as the "ignorant indigene hypothesis," this framework assumes that technological innovations were developed elsewhere and were introduced into a subject area either through diffusion of ideas or actual movement of populations. Prior to arrival of these ideas/people, local groups could not or would not develop a new adaptation on their own. From either perspective, marine mammal exploitation is often considered a relatively recent development, consistent with the view that coastal resources are either poor quality and second-rate or demand specialized adaptations. Chartkoff and Chartkoff (1984:40), for example, suggested that paleo-Indians in California "lacked the knowledge" to exploit the shellfish, acorns, and fish and only much later in time could "the rich potential of ocean resources be realized more fully" (Chartkoff and Chartkoff 1984:108). Although some prehistorians recognized early on that fur seal and sea lion rookeries could be effectively exploited with a simple technology (e.g., a club and a lance), the apparent restriction of rookeries to islands and offshore rocks meant that their pursuit also required watercraft. With notable exceptions (e.g., Engelbrecht and Seyfert 1994; Fladmark 1979), watercraft is often perceived as a relatively recent innovation in western North American prehistory. 
Our model confronts many cultural evolutionary/migrationist assumptions. First, we recognize that the value of marine resources, including seals and sea lions, is highly variable and situational and will depend on latitude, type of coast, and productivity of adjacent terrestrial habitats. Moreover, some marine resources, such as shellfish and pinnipeds, cannot be uniformly characterized as second-rate or inferior, nor does their acquisition require sophisticated technology. Initial human exploitation of pinnipeds did not require watercraft because some rookeries were present on the mainland. Simple boats were used to access island habitats very early along the California coast based on radiocarbon dates from the northern (Erlandson 1994:182) and southern (Salls 1992:166) Channel Islands, which were occupied as early as 10,000 years ago. More elaborate plank canoes and large oceangoing dugouts were developed later to $\mathrm{fa}-$ cilitate exploitation of more elusive taxa.

\section{Sea Temperatures and Cultural Ecology}

Models emphasizing changing sea temperatures have been advanced by archaeologists from the University of California, Santa Barbara in a series of publications (Davenport et al. 1993; Glassow 1992; Glassow et al. 1988; Walker et al. 1989). Advocates posit that Holocene changes in ocean water temperature strongly influenced the productivity of marine environments and, in turn, influenced subsistence vitality and cultural change. With respect to marine mammals, Glassow et al, (1988:75) suggest that seal and sea lion pursuit was strongly encouraged, if not initiated, in the Santa Barbara Channel by a decline in sea water temperatures ca. 3400 B.C. An increase in nearshore productivity caused by the colder ocean waters fostered an increase in sea mammal populations, rendering them more available to growing human populations. Later, ca. A.D. 500, marine produc- tivity declined as a result of warmer seas (Pisias 1979), causing resource stress (Walker et al. 1989:351) and an increased presence of southern ichthyofauna (Davenport et al. 1993).

In our conception of the maritime prehistory of western North America, California coastal hunter-gatherers were not so heavily impacted by large-scale environmental flux, but instead were fully capable of transcending environmental change and influencing the productivity of resources upon which they depended. Nonresident fur seals and sea lions on the California and Oregon coasts migrated between the mainland of Mexico and the Aleutian Islands and, therefore, changes in the availability of these animals observed in archaeological contexts throughout California and Oregon could not have resulted from localized changes in water temperature along the southern California coast. In contrast to the sea temperature model, we argue that migratory sea mammal rookeries were potentially important resources at the onset of human coastal occupation, which on the southern California coast predated the mid-Holocene by a considerable margin (Erlandson 1994; Erlandson and Colten 1991; Jones 1991; Lightfoot 1993). Later, diachronic change in their availability to prehistoric hunters is related to inevitable overexploitation, unrelated to changes in the marine environment.

\section{NeoMarxism}

A distinctive variant of the sea temperature model is advocated by Arnold (1991, 1992a, 1992b) and Colten (1993), who associate a period of inordinately high water temperatures between ca. A.D. 1150 and 1250 in the Santa Barbara Channel with deterioration of marine habitats. In the face of this catastrophe, craft specialization arose, as elites conspired to maintain and advance their socioeconomic positions. 
According to this model, the highly intensified Chumash maritime economy associated with a chiefdom type of sociopolitical organization (King 1982; Martz 1992) dates no earlier than ca. A.D. 1200.

From our perspective, the plank canoe, used ethnographically for island-mainland commerce, fishing, and marine mammal hunting, and initially used no later than A.D. 900 (King 1990:28, 233) and probably earlier, is a more significant marker of intensified subsistence than an increase in elite conspiracy (see also King 1982). Its development was coeval with the decreased availability of migratory marine mammals and concomitant development of other more sophisticated, labor-intensive marine technologies (e.g., composite harpoons). The co-occurrence of sophisticated technologies and complex sociopolitical organization, particularly where advanced watercraft was also employed (e.g., the Santa Barbara Channel and the northwest coast of California), indicates that capital-intensive production of plank canoes and ocean-going dugouts was a key variable in the development of complex hunter-gatherer cultures in coastal settings.

\section{Resource Management and Enhancement}

In questioning our model of intensification and overexploitation, Lyman (1991a, $1991 \mathrm{~b}$, this volume) has proposed that purposeful selection by prehistoric hunters actually improved the population vitality of northeastern Pacific pinnipeds: "prehistoric culling may have enhanced individual survival and thus possibly resulted in larger populations than would have been found had the sea mammals not been exploited by prehistoric people." Because the most desirable animals would have been more carefully managed than others, such a strategy would be reflected archaeologically by an overrepresentation of the most expendable age-sex classes (i.e., mature males) and a consistent presence of the most economically valuable species. This scenario is very different from the way we envision the prehistory of marine mammal use and conflicts with patterns we have identified in the zooarchaeological record. Although age-sex information is not widely available, Lyman's statistical analysis of our data demonstrates significant change in the mix of species over time in most areas, with economically valuable migratory taxa decreasing at the expense of lower-ranked species.

Lyman's reanalysis of the findings from the Point Mugu site on the southern California coast (this volume), originally reported by Lyon (1937), further demonstrates the absence of a resource management approach to sea mammal procurement. He states, ". . . the remains of females are over twenty times more frequent than the remains of males. ... If females were in fact being heavily exploited whereas males were rarely exploited, then hunters who deposited these remains were not taking individuals in an optimal fashion in the sense that harvesting would result in population maintenance. Because pinnipeds are polygynous, males can be harvested at relatively high rates without seriously impacting the population." These data clearly show that resource management and optimal foraging are largely unrelated and, more often than not, at odds with one another. While the prehistoric hunters of Point Mugu may not have been considering the long-term maintenance of fur seal populations, such behavior is fully consistent with optimal foraging theory which focuses on shortterm decision making and not potential availability of resources down the line. In targeting females and juveniles, the Point Mugu hunters were indeed behaving in an optimal fashion based on outputs of hunting effort versus potential returns. In terms of ease of capture, juveniles and fe- 
males would both be highly ranked, as males are found in low numbers at rookeries and are significantly more dangerous to approach and considerably more difficult to dispatch.

\section{DIFFERENTIAL REPRODUCTIVE BEHAVIOR AMONG PREY SPECIES}

Before presenting a reanalysis of the archaeofaunal data base, it is important to address disagreements between Lyman and ourselves regarding the significance of historically recorded differences in the reproductive behavior among marine mammal taxa exploited by prehistoric hunters along the Oregon and California coasts. These differences in behavior are crucial to our model as they signal changes in the availability of prey species (and changing costs associated with their procurement), as well as the range of adaptive responses on the part of prehistoric hunters. Hildebrandt (1981, 1984a) and Hildebrandt and Jones (1992) have divided prey species into two groups based on their differential availability during the breeding season. The first group, termed "migratory breeders," includes the Steller sea lion (Eumetopias jubata), California sea lion (Zalophus californianus), northern fur seal (Callorhinus ursinus), and southern fur seal (Arctocephalus toumsendi). None of these animals regularly breed or give birth while in the water. Instead, large dominant males establish territories on offshore rocks and islands in late spring in order to control harems of the smaller females who give birth and breed soon after arriving at the rookeries in early summer. Because the pups are unable to swim for a period of 1 to 2 months, the rookeries remain occupied until mid-summer at which time the animals disperse on their annual migrations (Fiscus 1978; Mate 1975; Scheffer 1958).

The second group, "resident breeders," includes the harbor seal (Phoca vitulina) and sea otter (Enhydra lutris). Both of these species have the potential to breed and give birth in the water, are not migratory, do not form large harems, and have little sexual dimorphism. Harbor seals are known to haulout on sand splits and offshore rocks during the pupping season (Lyman; this volume); however, such localities are abandoned at the slightest sign of danger because the pups are born with the ability to swim. Although sea otter pups cannot swim for about 2 weeks, they are either carried on their mother's chests or left floating on the surface while mothers forage for food, buoyed by air pockets in their thick fur (Kenyon 1978, 1982; Love 1990).

Both migratory and resident breeders haulout at other times of the year, but all groups quickly take to the water when disturbed, becoming more elusive prey by virtue of occupying the pelagic environment. Due to the technological constraints associated with pelagic hunting, we argued that migratory breeders in reproductive mode could have been procured with relatively low pursuit costs and, therefore, their rookeries would have been the focus of native hunting activities (Hildebrandt and Jones 1992:367).

Lyman questions the significance of these differences in reproductive behavior, noting that although harbor seals do not establish rookeries, "newborns are often found in nursery groups and breeding colonies, and nursing females show a high level of fidelity for returning to these loci to nurse their pups" (Lyman; this volume). He also questions the significance of traits assigned to migratory breeders, citing a series of exceptional cases where northern fur seals and California sea lions have been seen copulating in deep water (Baker 1989; Peterson and Bartholomew 1967) and precocious pups observed struggling in the water soon after being born (King 1983; Loughlin et al. 1987). Although these exceptions no doubt occur from time to time, 
it is the long-term, physiologically determined behaviors of these animals that provide the most accurate measure of the costs and benefits associated with their capture. The fact that harbor seals currently form nursing colonies along protected portions of the coast is of minimal importance-what matters is the range of behavioral responses that are possible under conditions of predatory stress. The fundamental point is that harbor seals and sea otters have the potential to reproduce in pelagic settings when suffering from predatory stress, while migratory breeders do not.

The long-term stability of these reproductive behaviors is clearly illustrated by a number of key social and physiological characteristics (Table 1). First, animals that can breed and give birth in the water (i.e., sea otters and harbor seals) do not form harems, while those requiring terrestrial settings for reproduction (i.e., Steller sea lion, California sea lion, northern fur seal, and southern fur seal) do form harems. This contrast is also reflected by the differential sexual dimorphism exhibited by the two groups of animals. Whereas resident breeders have an average female:male weight ratio of only $1: 1.2 \mathrm{~kg}$ (i.e., they are roughly the same size), migratory breeder males are about 3.5 times larger than the females $(1: 3.7 \mathrm{~kg})$. It follows, therefore, that this degree of sexual dimorphism could only have evolved among taxa using terrestrial settings for reproduction, as it would be impossible for dominant males to control a harem within an aquatic environment (see also Bartholomew 1970). Furthermore, it seems quite clear that these differences in reproductive behavior developed long ago and have remained stable throughout the entire history of human occupation of the western North American coast.

\section{LOCUS OF CAPTURE}

The above behavioral patterns, when combined with a widespread increase through time in the frequency of resident breeder archaeofaunas relative to migratory breeder remains, led us to conclude that prior to the significant occupation of the coast by human populations, migratory breeders regularly used mainland contexts for the purposes of reproduction:

Easily accessible to terrestrial hunters, these hypothetical mainland breeding colonies were exploited so heavily that they were eliminated relatively quickly, leaving offshore contexts as the only viable sites for continued breeding. Coastal areas lacking offshore rocks or islands were essentially left with resident populations of harbor seal and sea otter, who could reproduce without forming long-term, non-aquatic breeding colonies. Under such circumstances, terrestrial resources tended to become the major focus of intensification. ... In areas where offshore rocks and/or islands were present.... local inhabitants intensified their approach to marine mammal hunting through the develop-

TABLE 1

Behavioral and Physiological Differences among Key Marine Mammal Taxa

\begin{tabular}{lcccccc}
\hline & \multirow{2}{*}{$\begin{array}{c}\text { Breed/birth } \\
\text { in water }\end{array}$} & $\begin{array}{c}\text { Form } \\
\text { harems }\end{array}$ & Migrate & Female & Male & $\begin{array}{r}\text { Female/male } \\
\text { weight ratio }\end{array}$ \\
\hline Sea otter & + & - & - & 32 & 45 & $1: 1.4$ \\
Harbor seal & + & - & - & 110 & 115 & $1: 1.0$ \\
Steller sea lion & - & + & + & 270 & 990 & $1: 3.7$ \\
California sea lion & - & + & + & 112 & 360 & $1: 3.2$ \\
Northern fur seal & - & + & + & 62 & 270 & $1: 4.4$ \\
Southern fur seal & - & + & + & 45 & $\mathbf{1 6 0}$ & $1: 3.6$ \\
\hline
\end{tabular}

Note. Weight in kilograms. 
ment of watercraft. Although this innovation a]lowed access to the vulnerable offshore rookeries, breeding populations appear to have maintained themselves because of the high pursuit and transport costs associated with marine travel. (Hildebrandt and Jones 1992:388-389)

Although Lyman (this volume) agrees that the reproductive behaviors of migratory breeders makes them more susceptible to predation, he argues that mere presence of their remains in archaeofaunal assemblages does not necessarily indicate they were obtained from rookeries, nor does it indicate the locus of their capture (i.e., whether they were obtained pelagically, from offshore rocks, or simply from the mainland). Instead, he feels that until we develop robust age-sex data in our archaeofaunal assemblages, it will not be possible to demonstrate that prehistoric hunters were actually exploiting the rookeries of migratory breeders. Furthermore, Lyman argues that we presently lack the data necessary to assign values to resident breeders and migratory breeders indicating the probability of whether they were procured in pelagic or terrestrial settings, nor can we measure the relative amount of time each group spends on land (whether on a rookery or haulout). Both of these problems, according to Lyman, prevent us from making accurate comparisons of the relative accessibility of migratory and resident breeders to terrestrial predators.

While it is true that we cannot unequivocally determine that migratory breeders were largely obtained from rookeries and resident breeders were not (i.e., age-sex data are not available), we are still able to demonstrate that: (1) migratory breeders were obtained from mainland settings prior to long-term human occupation of the coast, often in areas lacking adjacent offshore rocks; (2) once the coast was settled, mainland hunting intensity increased, pushing migratory breeders to offshore rocks and islands; (3) once this transition occurred, migratory breeders were rarely exploited in areas lacking offshore rocks; and (4) irrespective of time period, resident breeders were never obtained in great numbers from offshore rocks. We believe that these trends, combined with the reproductive behavior of the prey and the ethnographic distribution of sophisticated watercraft, provide ample support for the intensification model outlined above.

Our previous analyses of the archaeofaunal assemblages from the Oregon and California coasts focused on changes in the mix of migratory and resident taxa over time, with little emphasis placed on the locus of their capture. In response to Lyman's critique, we have improved our analysis by organizing the data into four groups (Tables 2-4): (1) mainland sites adjacent to offshore rocks with known migratory breeder rookeries and/or haulouts, (2) mainland sites lacking adjacent offshore rocks with known migratory breeder rookeries/haulouts, (3) mainland sites adjacent to estuaries, and (4) sites on islands. With respect to the first group of sites, we have used historically recorded migratory breeder rookeries and haulouts, rather than just rookeries, because both settings provide a good measure of potential rookery habitats without relying on the abbreviated list of breeding grounds compiled by Bonnet (1928; see Lyman's critique of the Bonnet rookery study, this volume). We have also not distinguished between rocks/islands that are well offshore and those located in relatively near-shore contexts, as this difference appears to have little affect on the mix of faunal remains recovered, although it most certainly influenced the kinds of watercraft that were used (see Jobson and Hildebrandt 1980). The four groups of assemblages have been further divided into three temporal periods: $6000-2000$ B.C., 2000 B.C.-A.D. 500, and post-A.D. 500. Although this simple sequence obscures some temporal resolution in places where more precise chronol- 
ogies exist (see Hildebrandt and Jones 1992; Lyman; this volume), it allows all localities to be placed within the same temporal frame-work, facilitating widespread chronological comparisons.

Beginning with the earliest period (6000-2000 B.C.), archaeofaunal assemblages from outer coast settings are limited to a single site located near Duncan's Landing in Sonoma County (Schwaderer 1992). It lacks adjacent offshore rocks and its mid-Holocene components produced relatively equal numbers of migratory and resident breeder remains (Table 2 ). It should be noted that the near-absence of early assemblages from outer coast contexts does not reflect a nominal use of coastal environments during this interval, because numerous middle and early Holocene components have been recorded along the California and Oregon coasts (Erlandson 1994; Jones 1991; Lyman 1991a). Instead, it appears that excavation samples are either too small, or the poor preservation of bone precludes the development of useful comparative data. The availability of data is better from island and estuary settings, both of which have also produced the greatest number of early
Holocene components in coastal California (see Jones 1991, 1992). The estuary samples, obtained from Elkhorn Slough and San Francisco Bay, show a dominance of resident breeders, clearly due to their propensity to occupy such settings and the lack of this tendency among migratory breeders. The Channel Island samples show the opposite relationship, as San Miguel Island and San Nicolas Island both have a dominant presence of migratory breeders. Given that the Islands were inhabited as early as 8000 B.C., it appears that the intensity of these occupations was not high enough to adversely effect migratory breeder populations until later in time (see below).

Between 2000 B.C. and A.D. 500 the record expands to include a greater number of outer coast settings; however, the vast majority of sites lack adjacent offshore rocks with known migratory breeder haulouts and/or rookeries (Table 3). Despite the fact that migratory breeders did not historically use these areas for hauling out or breeding, all six locations (Seaside, Whale Cove, Yaquina Head, Mendocino, Duncan's Landing, and Monterey) produced relatively large numbers of their re-

TABLE 2

Archaeofaunal Assemblages from California Dating between 6000 and 2000 B.C.

\begin{tabular}{|c|c|c|c|c|c|c|c|}
\hline & \multicolumn{2}{|c|}{$\begin{array}{l}\text { Migratory } \\
\text { NISP (\%) }\end{array}$} & \multicolumn{2}{|c|}{$\begin{array}{l}\text { Resident } \\
\text { NISP (\%) }\end{array}$} & $\begin{array}{c}\text { Marine } \\
\text { total }\end{array}$ & $\begin{array}{c}\text { Deer/elk } \\
\text { NISP }\end{array}$ & $\begin{array}{c}\text { Grand } \\
\text { total }\end{array}$ \\
\hline \multicolumn{8}{|c|}{ With haulouts and/or rookeries } \\
\hline No data available & - & - & - & - & - & - & - \\
\hline \multicolumn{8}{|c|}{ Without haulouts and/or rookeries } \\
\hline Duncan's Landing & 26 & 46.4 & 30 & 53.7 & 56 & $\longrightarrow$ & 56 \\
\hline \multicolumn{8}{|c|}{ Estuaries } \\
\hline S.F. Bay & 3 & 20.0 & 12 & 80.0 & 15 & 22 & 37 \\
\hline Elkhorn Slough & 7 & 25.0 & 21 & 75.0 & 28 & 65 & 93 \\
\hline Total & 10 & 23.3 & 33 & 76.7 & 43 & 87 & 130 \\
\hline Mean percentage & - & 22.5 & 一 & 77.5 & - & - & - \\
\hline \multicolumn{8}{|c|}{ Islands } \\
\hline San Miguel Island & 285 & 75.0 & 95 & 25.0 & 380 & - & - \\
\hline San Nicolas Island & 266 & 70.4 & 112 & 29.6 & 378 & - & $\longrightarrow$ \\
\hline Total & 551 & 72.7 & 207 & 27.3 & 758 & - & - \\
\hline Mean percentage & - & 72.7 & - & 27.3 & - & - & - \\
\hline
\end{tabular}


TABLE 3

Archaeofaunal Assemblages from Oregon and California Dating ca. 2000 B.C.-A.D. 500

\begin{tabular}{|c|c|c|c|c|c|c|c|}
\hline & \multicolumn{2}{|c|}{$\begin{array}{l}\text { Migratory } \\
\text { NISP (\%) }\end{array}$} & \multicolumn{2}{|c|}{$\begin{array}{l}\text { Resident } \\
\text { NISP (\%) }\end{array}$} & $\begin{array}{c}\text { Marine } \\
\text { total }\end{array}$ & $\begin{array}{c}\text { Deer/elk } \\
\text { NISP }\end{array}$ & $\begin{array}{c}\text { Grand } \\
\text { total }\end{array}$ \\
\hline \multicolumn{8}{|c|}{ With haulouts and/or rookeries } \\
\hline San Mateo-A & 142 & 95.9 & 6 & 4.1 & 148 & 21 & 169 \\
\hline \multicolumn{8}{|c|}{ Without haulouts and/or rookeries } \\
\hline Seaside & 42 & 53.8 & 36 & 46.2 & 78 & 37 & 115 \\
\hline Whale Cove & 43 & 72.9 & 16 & 27.1 & 59 & 166 & 225 \\
\hline Yaquina Head & 30 & 31.6 & 65 & 68.4 & 95 & 148 & 243 \\
\hline Mendocino & 185 & 84.9 & 33 & 15.1 & 218 & 245 & 463 \\
\hline Duncan's Landing & 8 & 57.1 & 6 & 42.9 & 14 & - & 14 \\
\hline Monterey & 69 & 75.0 & 23 & 25.0 & 92 & 66 & 158 \\
\hline Total & 377 & 67.8 & 179 & 32.2 & 556 & 662 & 1218 \\
\hline Mean percentage & - & 62.6 & - & 37.4 & - & - & - \\
\hline \multicolumn{8}{|c|}{ Estuaries } \\
\hline Umpqua Eden & 20 & 10.0 & 181 & 90.0 & 201 & 29 & 230 \\
\hline S.F. Bay & 627 & 11.7 & 4736 & 88.3 & 5363 & 5905 & 11268 \\
\hline Elkhorn Slough & 29 & 17.4 & 138 & 82.6 & 167 & 433 & 600 \\
\hline Total & 676 & 11.8 & 5055 & 88.2 & 5731 & 6367 & 12098 \\
\hline Mean percentage & - & 13.0 & - & 87.0 & - & - & - \\
\hline \multicolumn{8}{|c|}{ Islands } \\
\hline San Miguel Island & 81 & 69.8 & 35 & 30.2 & 116 & - & - \\
\hline San Nicolas Island & 87 & 30.9 & 195 & 69.1 & 282 & - & - \\
\hline Total & 168 & 42.2 & 230 & 57.8 & 398 & - & - \\
\hline Mean percentage & - & 50.4 & - & 49.6 & - & - & - \\
\hline
\end{tabular}

Note. San Mateo-A includes SMA-218.

mains. When the data from these locations are combined, migratory breeder elements outnumber resident breeder remains at a rate of $377(67.8 \%)$ to $179(32.2 \%)$. This relationship is best demonstrated at Whale Cove, Mendocino, and Monterey, while the relative frequency of migratory breeders is lower at Seaside, Yaquina Head, and Duncan's Landing.

The single area located next to a known migratory breeder rookery/haulout area (San Mateo-A) also shows a dominance of migratory breeder remains. Given the presence of migratory breeders at the six areas lacking adjacent offshore rocks (where they were presumably obtained from mainland contexts), we must agree with Lyman that for this temporal interval, there is no way to determine whether or not the migratory breeder remains recovered from San Mateo-A reflect a mainland or offshore locus of capture. Estuary settings, following a pattern consistent with the $6000-2000$ B.C. interval, maintain a dominant presence of resident breeder remains. The Channel Island samples diverge from one another, with San Miguel maintaining a dominance of migratory breeders and San Nicolas showing a significant increase in the number of resident breeder remains.

By the Late Period (post-A.D. 500), the relationships originally identified by Hildebrandt and Jones (1992) clearly come into play; that is, large numbers of migratory breeder remains are only found in sites located adjacent to offshore rocks with known haulouts and/or rookeries (Table 4). Whereas migratory breeders represent $67.8 \%$ of the combined 2000 B.C.A.D. 500 sample from sites lacking adjacent haulouts/rookeries, their contribution 
TABLE 4

Archaeofaunal Assemblages from Oregon and California Post-dating A.D. 500

\begin{tabular}{|c|c|c|c|c|c|c|c|}
\hline & \multicolumn{2}{|c|}{$\begin{array}{l}\text { Migratory } \\
\text { NISP (\%) }\end{array}$} & \multicolumn{2}{|c|}{$\begin{array}{l}\text { Resident } \\
\text { NISP (\%) }\end{array}$} & $\begin{array}{c}\text { Marine } \\
\text { total }\end{array}$ & $\begin{array}{c}\text { Deer/elk } \\
\text { NISP }\end{array}$ & $\begin{array}{c}\text { Grand } \\
\text { total }\end{array}$ \\
\hline \multicolumn{8}{|c|}{ With haulouts and/or rookeries } \\
\hline Ecola Point & 152 & 72.0 & 59 & 28.0 & 211 & 37 & 248 \\
\hline Seal Rock & 1112 & 86.5 & 174 & 13.5 & 1286 & 511 & 1797 \\
\hline Pt. St. George & 263 & 86.2 & 42 & 13.8 & 305 & 44 & 349 \\
\hline Stone Lagoon & 100 & 91.7 & 9 & 8.3 & 109 & 59 & 168 \\
\hline Patrick's Point & 34 & 66.7 & 17 & 33.3 & 51 & 32 & 83 \\
\hline Mattole River & 146 & 67.9 & 69 & 32.1 & 215 & 212 & 427 \\
\hline Total & 1807 & 83.0 & 370 & 17.0 & 2177 & 895 & 3072 \\
\hline Mean percentage & - & 78.5 & - & 21.5 & - & - & - \\
\hline \multicolumn{8}{|c|}{ Without haulouts and/or rookeries } \\
\hline Seaside & 9 & 16.4 & 468 & 83.6 & 55 & 6 & 61 \\
\hline Whale Cove & 3 & 3.7 & 78 & 96.3 & 81 & 19 & 100 \\
\hline Yaquina Head & 24 & 17.7 & 112 & 82.4 & 136 & 49 & 185 \\
\hline Spanish Flat & 32 & 82.1 & 7 & 17.9 & 39 & 402 & 441 \\
\hline Shelter Cove & 46 & 52.9 & 41 & 47.1 & 87 & 292 & 379 \\
\hline Mendocino & 6 & 5.9 & 96 & 94.1 & 102 & 106 & 208 \\
\hline San Mateo-B & 46 & 5.6 & 767 & 94.3 & 87 & 292 & 379 \\
\hline Monterey & 10 & 52.6 & 9 & 47.4 & 19 & 135 & 154 \\
\hline Total & 176 & 13.2 & 1156 & 86.8 & 1332 & 1105 & 2437 \\
\hline Mean percentage & - & 29.6 & - & 70.4 & - & - & - \\
\hline \multicolumn{8}{|c|}{ Estuaries } \\
\hline Umpqua-Eden & 47 & 12.7 & 324 & 87.3 & 371 & 134 & 505 \\
\hline Gunther Island & 21 & 31.3 & 46 & 68.7 & 67 & 119 & 186 \\
\hline S.F. Bay & 11 & 0.9 & 1201 & 99.1 & 1212 & 572 & 1784 \\
\hline Total & 79 & 4.8 & 1571 & 95.2 & 1650 & 825 & 2475 \\
\hline Mean percentage & - & 15.0 & - & 85.0 & - & - & - \\
\hline \multicolumn{8}{|c|}{ Islands } \\
\hline San Miguel Island & 20 & 41.7 & 28 & 58.3 & 48 & - & - \\
\hline San Nicolas Island & 303 & 47.2 & 339 & 52.8 & 642 & - & - \\
\hline Total & 323 & 46.8 & 367 & 53.2 & 690 & - & - \\
\hline Mean percentage & - & 44.4 & - & 55.6 & - & - & - \\
\hline
\end{tabular}

Note. San Mateo-B includes SMA-72, SMA-97, SMA-115, and SMA-118.

drops to only $13.2 \%$ within the combined late period sample obtained from similar environmental settings. Although some variability exists from one locality to the next in the proportion of these animals, the relative frequency of migratory breeders drops in all cases where both the 2000 B.C.-A.D. 500 and post-A.D. 500 components are represented: Seaside $(53.8 \%$ to $16.4 \%)$, Whale Cove $(72.9 \%$ to $3.7 \%)$, Yaquina Head (31.6\% to $17.7 \%$ ), Mendocino $(84.9 \%$ to $5.9 \%)$, and Monterey (75.0\% to $52.6 \%$ ). Late period locations lacking comparative data from the earlier 2000 B.C.-A.D. 500 interval produced mixed results. Whereas San Mateo-B conforms to our expectations (migratory breeders comprised only $5.6 \%$ of the assemblage), Spanish Flat and Shelter Cove both produced relatively high frequencies of migratory breeder remains ( 82.1 and $52.9 \%$, respectively).

Results from Late Period sites located adjacent to known rookeries/haulouts have clear, definitive implications (Table 4). The abrupt increase in the number of 
sites situated adjacent to haulouts/ rookeries may reflect a shift in the availability of migratory breeders, or may be simply the outcome of a higher number of sites in all outer coast settings late in time. A review of archaeofaunal assemblages from sites near haulouts/rookeries, however, supports the former alternative, as all six locations are dominated by the remains of migratory breeders. Ranging from $66.7 \%$ to $91.7 \%$, the combined assemblages include $83.0 \%$ migratory and $17.0 \%$ resident remains, in direct contrast to Late Period areas lacking offshore haulouts/ rookeries where the opposite relationship exists (migratory $=13.2 \%$, resident $=$ $86.8 \%$ ).

As correctly recognized by Lyman (this volume), it is also important to consider the results of a recent archaeological survey of offshore rocks along the southern Oregon coast by Gard (1992). Two of the rocks exhibiting obvious evidence of prehistoric occupation (i.e., shellfish, fish bone, pinniped remains) produced uncorrected radiocarbon dates on charcoal of 860 \pm 50 years B.P. and $1840 \pm 70$ years B.P. Although the latter date is somewhat earlier than our late period boundary of A.D. 500 , both dates provide direct evidence for the use of offshore rocks relatively late in time.

The Late Period estuary sample, dominated by resident breeders, is consistent with earlier findings. It is also interesting to note that the relative frequencies produced by the estuary samples (irrespective of time period) are quite similar to the combined Late Period sample obtained from outer coast sites lacking adjacent haulouts/ rookeries, reflecting the disuse of both environments by migratory breeders during the Late Period and estuaries throughout the entire sequence. Finally, the Channel Island samples produce significant amounts of both resident and migratory breeder remains, probably reflecting the inability of island hunters to sustain an im- pact on migratory breeders equivalent to that of their mainland counterparts (see below).

Although Lyman is correct in arguing that we cannot clearly distinguish between animals obtained from rookeries and those captured from haulouts without age-sex information, the data outlined above clearly indicate that prior to A.D. 500 , migratory breeders were regularly obtained in areas lacking offshore rocks, presumably when they occupied the mainland while breeding or hauling out. After A.D. 500 , it seems obvious that the availability of migratory breeders in these contexts declined, leading to a more intensive exploitation of offshore rocks, many of which are currently used as rookeries. It follows, therefore, that migratory breeders did not maintain rookeries or large-scale haulouts on the unprotected mainland during the late period. Instead, their terrestrial activities were largely limited to offshore contexts. Whether they were predominantly hunted at rookeries or haulouts remains an open question; nevertheless, the costs associated with their capture undoubtedly increased over time.

\section{HISTORICAL RECOLONIZATION}

Critical to our argument is the inability of migratory breeders to colonize and recolonize mainland and island rookeries rapidly when freed from predatory stress. Our statement that "only recently after over 100 years free of human and nonhuman predation have any of these taxa expanded their breeding sites to easily accessible mainland locations" is based on well-documented historical fact. Contrary to Lyman's proposal that marine mammal recolonization has transpired rapidly over the last 20 years, historical recolonization by the heavily predated taxa has occurred slowly and gradually over the last century or so. Mainland rookeries, the last to be reestablished, demonstrate that these ani- 
mals are not biologically restricted to islands, and are capable of expanding their populations to the mainland. Recolonization of the mainland in the absence of terrestrially based predation should be considered inevitable.

Exploitation of northern Pacific seal and sea lions during the historic era and their subsequent population revival has been well documented by Le Boeuf (1981), and much of the following discussion comes from that source. There is interspecific variability in the chronology of population decimation and eventual rebound, but the length of time required for the latter is much longer than that proposed by Lyman.

Seals and sea lions were first hunted off California shores for their hides and oil as early as the first half of the nineteenth century. Northern elephant seals were a preferred target for oil because they were slow and unafraid of humans. Pursued intensively for 40 years, their population history is summarized as follows:

By 1860 , the population was so depleted that elephant seals were no longer considered an economically feasible source of oil; by 1869 the species was considered virtually extinct. By 1884 no elephant seals were seen any where, despite the fact that several museum expeditions made thorough searches for them. However, in 1899, C. H. Townsend on a collecting expedition for the Smithsonian Institution was surprised to find 8 elephant seals on . . Isla de Guadalupe. The museum collector killed seven of the seals. (Le Boeuf 1981:296-297)

Le Boeuf (1981:297) further notes that 1892 was "unquestionably the low point in the population's history." This species, which had in the early 1800 s bred as far north as Point Reyes (Scammon 1874) on the central California coast, began its return on Guadalupe Island, aided in 1922 by legislative protection from the Mexican government (Le Boeuf 1981:297). The animals were not seen off central California until 1948, and their first birth was recorded in 1961. In 1975 , the breeding population expanded to the mainland at Point Año Nuevo, and the rookeries at that location have grown significantly since that time. Despite the fact that 100 years have passed since the population low of 1892, they have yet to reestablish themselves throughout their original territory along the California coast.

California and Steller sea lions replaced the elephant seal as major sources of industrial oil when elephant seals became scarce in 1860 . By the 1870 s, the sea lion population was severely depleted and was no longer considered a viable source of oil, although some animals were still hunted for their hides. In contrast with the elephant seals, some sea lion rookeries persisted, and the species was subjected to reduced but ongoing harassment, after reaching their low population point in the 1870s. Between 1900 and 1909 sea lions, considered threats to commercial fishing, were systematically killed by government deputies. These species were not seen at Point Año Nuevo until the 1920s, and in 1927, the entire population in California was thought to number 941 individuals (Bonnott 1928). By 1978, however, this figure reached 50,000 (Bonnell et al. 1978). The return of these species was more rapid than the recolonization by elephant seals, because the population was not taken as close to total extinction. Nonetheless, recovery was not instantaneous.

Southern and northern fur seals were also hunted for their hides. According to Scheffer (1958), over 70,000 southern fur seal skins were taken between 1810 and 1812 , but this number dropped to around 200-300 per year during the next two decades. Populations have been slow to recover, as only one rookery has been identified (Guadalupe Island off Baja California) and only 2000 individuals were known to exist as of 1980 (Le Boeuf and Bonnell 1980). Northern fur seal breeding 
populations on the Pribilof Islands probably exceeded 2.5 million in the late $1700 \mathrm{~s}$, but dropped to less than 300,000 in 1835 and, following an abbreviated rebound, decreased to around 200,000 in 1911. After the development of controlled harvesting strategies during this period of population lows, their numbers increased again, reaching about 1.8 million by 1979 (Gentry 1981; King 1983; Lyman this volume). Although we originally oversimplified the history of human involvement with large migratory pinnipeds (i.e., they have not been free of predation for 100 years), a full population rebound has not yet occurred, suggesting that the process of reestablishment takes at least $50-100$ years.

Harbor seals were never hunted systematically for their pelts or oil, and their populations never experienced the population bottleneck inflicted on the larger migratory pinnipeds. Because of their elusive behavior this condition existed in the prehistoric past as well. Harbor seals were present in significant numbers and represented a viable, but costly, alternative to the larger taxa when the latter had been overexploited.

Sea otters present an even more convoluted situation. Their commercial exploitation along the northern coast began in 1741 and continued intensely for 170 years, when they were legislatively protected. Prehistorically they ranged from central Baja California to the Aleutian Islands. At the time of their protection, they were commercially extinct and close to biologically extinct. A few animals were noted by government personnel during the first few decades of the 20th century, but a significant breeding population was not recognized until 1938 along the Big Sur coast of Monterey County. By 1957, the permanent population of California, situated between Point Conception and Monterey Bay, had reached 638 individuals (Kenyon 1969: $186)$. By 1966 , the population of this terri- tory was essentially the same; however, the overall population was continuing to grow by expanding into adjacent territories which were still only part of its overall former range. From one perspective, renewal of the otter population required about 50 years; on the other, the otters still have not repopulated all of their former territory.

\section{EXCEPTIONAL CASES}

Regional prehistories not conforming with our expectations do not undermine the overall utility of our model. The coevolution of marine mammal hunting strategies and maritime hunter-gatherer culture should be examined at several different scales, due to the unique migratory behavior of these animals. A model of overexploitation, or any explanatory construct giving serious consideration to pinniped population ecology must, on one level, consider the entire migration corridors of these animals. On the other hand, regional prehistories and individual site patterning must also be explained, and interregional variability should be expected. Indeed, exceptional cases should be welcomed, as overly uniform patterning in the archaeological record often signals something other than human cultural behavior (e.g., sample size or taphonomic bias).

Three main localities produced data indicating that migratory breeder populations rebound late in time. In all three cases, however, it appears that changes in the density and/or seasonal distribution of human populations may have provided renewed opportunities for migratory breeder populations on the mainland and portions of the Channel Islands. The following discussion pursues this possibility through a review of the larger environmental, archaeological, and ethnographic contexts for the three areas of California where exceptional patterns in the ar- 
chaeofaunal data base have been encountered: the Channel Islands, Monterey Bay, and northwestern California.

\section{The Channel Islands}

The Channel Islands provide an excellent example of the dynamic nature of human-pinniped interactions. Because fur seal and sea lion rookeries have apparently persisted on the islands from remote antiquity to the early historic period, accounting for patterns in their predation and perseverance is critical to a general model of marine mammal overexploitation. Human bone isotope results from early Holocene contexts at San Clemente Island (Goldberg 1989) indicate that sea mammals were exploited heavily by early inhabitants of the southern islands. Analysis of midden constituents from the northern islands likewise shows a dominant representation of sea mammals in the earliest occupational levels (Glassow 1993: 83). Consistent with the isotope and midden findings, data from San Miguel Island (see Hildebrandt and Jones 1992:387; Lyman, this volume) show an early $(6500$ 3500 B.C.) abundance of migratory breeders $(82.0 \%$ versus resident breeders) followed by a significant decrease during the $3500-1000$ B.C. temporal interval $(50.0 \%$ versus resident breeders). This trend is broken after 1000 B.C., when migratory breeders increase to $72.4 \%$ between 1000 B.C. and 1200 A.D. and drop again to $41.6 \%$ thereafter. New data from San Nicolas Island (see SNI-11, Table 4) reported by Bleitz-Sanburg (1987) follow a similar pattern, beginning with an early (pre-2000 B.C.) focus on migratory breeders $(70.4 \%)$, followed by a drop in frequency $(30.9 \%)$ between 2000 B.C. and 500 A.D., and a rebound later in time $(47.2 \%)$. We originally argued that migratory breeder populations could be expected to be more variable on remote islands than on the mainland because the former settings were subject to less constant human occupation. This is probably incorrect for the remote islands (e.g., San Clemente and particularly San Nicholas) as they required some effort to reach and were large enough to provide year-round subsistence for small human groups. Nevertheless, these remote outposts represented the last remaining refuge for rookeries, and despite constant human predatory pressure, migratory breeders had no place left to go beyond these islands.

The archaeological record up to the 1000 B.C.-A.D. 1200 interval conforms with patterns identified elsewhere: migratory breeders decrease and residents increase. Why does this trend reverse itself relatively late in time? Recent studies indicate that the transition from the terminal Middle Period into the Late Period along the central and southern California coasts was a time of significant environmental oscillation and severe cultural stress, particularly on the islands. Arnold (1992a) suggests that high sea water temperatures promoted degradation of marine habitats, but Raab et al. (1995) have correctly pointed out that no evidence for degraded marine productivity has ever been presented, and central and south coast shell middens dating to the A.D. 1000-1300 interval exhibit dense concentrations of fish remains which do not connote a marine catastrophe (Gerber 1993; Jones 1995; Raab 1994). Other studies of midden constituents (Arnold and Tissott 1993; Colten 1992, 1993) suggest a warming of sea temperatures, but simultaneously indicate the perseverance of shellfish and fish. There is, however, significant evidence for severe drought during this period (Graumlich 1993; Stine 1994). Both Arnold (1992b:134) and Raab et al. (1994) have identified occupational hiatuses on the islands during this interval that can be readily attributed not to decreased marine productivity, but to the drying up of water sources, which on many of the islands were initially 
limited. A similar drought during the early historic period contributed to the final $\mathrm{Na}$ tive abandonment of the northern Channel Islands (Larson et al. 1994). Departure of humans from many of the islands, and the continuing vitality of the marine ecosystem provided marine mammal populations with an opportunity to rebound. When exploitation began anew, the more highly ranked migratory breeders, present in greater numbers, were again pursued more heavily than harbor seals and sea otters.

\section{3vionterey Bay}

The Monterey Bay area also produced results contrary to expectations of the model. The Early (3000-500 B.C.) and Middle (500 B.C.-A.D. 1000) period assemblages both have large proportions of marine versus terrestrial remains (Early $=$ 81.6 to $18.4 \%$; Middle $=58.2$ to $41.8 \%$, respectively), and most of the marine mammal collection is represented by migratory breeders (Early $=58.8 \%$; Middle $=75.0 \%$ ). Given the lack of offshore rocks in the area, continued use of the coastal environment should have been reflected by a marked decrease in migratory breeders relative resident breeders after A.D. 1000 . Instead, migratory breeder bones continue to outnumber those of residential breeders (52.6\% to $47.4 \%$ ), and the overall frequency of all marine mammal taxa dropped relative to terrestrial remains (marine $=12.3 \%$, terrestrial $=87.7 \%$ ) .

Similar to the Channel Islands, the abundance of migratory breeders late in time may be in part due to a shift in landuse patterns over time (Dietz and Jackson 1981; Dietz et al. 1988; Jones 1992). Analysis of complete archaeological assemblages from the area indicate that prior to about A.D. 1000 , the Monterey region was occupied by small groups of people who made several residential moves between coastal and interior settings during an annual cy- cle. Many of these residential bases appear to have been used repeatedly over time, creating highly visible sites characterized by a wide variety of artifacts, features, and archaeofaunal remains. After the Middle/ Late Transition (A.D. 1000-1250), economies became increasingly focused on terrestrial foods, due to a greater reliance on stored resources (principally the acorn; see also Basgall 1987). Residential bases were established on the interior among the oak groves, while the coast was exploited by logistically organized groups who occupied the area for only limited amounts of ime. Spuradic, speciralirzed use of the Monterey coast during the Late Period may have allowed migratory breeders to reestablish mainland rookeries, or at the very least, haulouts would have been exploited less frequently, due to a reduction in the presence of human predators.

\section{Northwest California}

Although the northwest California data base dates only to the Late Period (postA.D. 500), the overall patterns observed at Spanish Flat and Shelter Cove are comparable to those encountered on the Channel Islands and Monterey Bay (Table 4). Sites north of Cape Mendocino, located adjacent to offshore rocks (Point St. George, Stone Lagoon, Patrick's Point) show a dominance of migratory breeders (averaging $81.5 \%$ versus resident taxa), and a high number of marine mammal remains in general (71.3\% versus terrestrial taxa). Areas south of Cape Mendocino lacking offshore rocks (Spanish Flat and Shelter Cove) produced only limited amounts of marine mammal bone (averaging only $15.9 \%$ versus terrestrial fauna), however, migratory breeders make up $67.5 \%$ of the marine mammal assemblages. Review of the ethnographic and archaeological records of northwest California indicates that north of Cape Mendocino, the Tolowa, Yurok, and Wiyot were concen- 
trated in coastal and riverine settings where the use of capital intensive technological systems (e.g., oceangoing canoes, fish weirs, plank smoke houses) not only facilitated the procurement and storage of marine mammals and fish, but also allowed the development of large, socially complex, sedentary villages (Fredrickson 1984; Gould 1975; Kroeber 1925). The late period archaeological record is consistent with this reconstruction, not only with respect to the abundance of migratory breeders in the sites, but also given the presence of formal houses, processing areas, stone pathways between activity areas, and discrete cemetery areas (Elsasser and Heizer 1966; Gould 1966; Milburn et al. 1979). In addition, the overall importance of sea lion hunting is also reflected by a small offshore rock located near Patrick's Point where approximately 1000 sea lion skulls appear to have been deposited apparently as part of some kind of unknown hunting ritual (Heizer 1951; see also Lyman this volume).

South of Cape Mendocino, in the vicinity of Spanish Flat and Shelter Cove, an entirely different situation is reflected by the ethnographic and archaeological records. The limited amount of ethnographic information that exists for this region indicates that the Mattole and Sinkyone did not form permanent coastal villages (Elsasser 1978:192; Kroeber 1925: 116). Instead, they focused on terrestrial and riverine resources, particularly anadromous fish and acorns which were stored and consumed while occupying interior winter villages. Excavation of 15 coastal sites within Mattole and Sinkyone territory (Levulett 1985; Levulett and Hildebrandt 1987) also found no evidence of permanent coastal settlement. Given the lack of intensive coastal occupation, it follows that migratory breeders may have attempted to colonize mainland settings from time to time.

\section{SUMMARY}

In his original work on the northern California coast, Hildebrandt (1981, 1984a) identified what he believed was a meaningful pattern in the archaeological record: north of Cape Mendocino there was a cooccurrence of offshore rocks with migratory breeder rookeries, nearby archaeological sites with abundant remains of migratory breeders and composite harpoon tips, and ethnographically recorded use of ocean-going canoes; south of Cape Mendocino in the absence of offshore rocks, sites showed lower frequencies of migratory breeders, few harpoon tips, and there were no ethnographic accounts of oceangoing canoe use. Based on these relationships, Hildebrandt (1981, 1984a) concluded that the northernmost groups used capital intensive watercraft to access offshore rocks, while the southern groups did not. This distinction contributed significantly to the intergroup variability in sociopolitical organization apparent in the ethnographic record.

Based on zooarchaeological findings from Oregon, where migratory breeder remains were found in settings lacking offshore rocks, Lyman (1989) argued that mainland rookeries must have existed in the past, and that the archaeological presence of these animals was not necessarily an indicator of the use of sophisticated watercraft. This was a positive contribution to the study of maritime hunting adaptations that led Hildebrandt and Jones (1992) to analyze archaeofaunas from a wide crosssection of the Oregon and California coasts. This analysis demonstrated a widespread early focus on migratory breeders (presumably in mainland settings) followed by an elimination of mainland breeding areas due to overhunting and the development of capital-intensive watercraft in areas where offshore rookeries were present. 
Lyman remains less than satisfied with our model because a lack of age/sex data prevents us from determining whether or not animals were obtained from rookeries or haulouts. He also is unconvinced of our ability to determine whether these animals were taken from mainland or offshore contexts. His thoughtful challenge has inspired us to again scrutinize the Oregon and California maritime fauna data base, this time looking more carefully at the environmental context of findings, in addition to our previous emphasis on temporal patterning. This reanalysis indicates that occupants of outer coasts and islands harvested migratory breeders in large numbers until ca. 1000 B.C. in southern California and approximately 1000-1500 years later in areas further north. At mainland areas adjacent to offshore rocks (irrespective of distance from the shore), migratory breeders continued to be pursued after these dates, but with the aid of sophisticated watercraft, and in conjunction with sedentary settlement organization. The rise of maritime sedentism, apparent in California only in the Santa Barbara Channel and the northwest coast, was intimately related to the development of sophisticated, labor-intensive watercraft, as a consequence of the overexploitation of migratory breeders and the need to pursue alternative species in more elusive offshore contexts.

In mainiand areas without offshore rocks, harbor seals and sea otters provided labor-intensive replacements for the migratory breeders. Complex watercraft were not recorded ethnographically in these areas. As Lyman notes some localities lacking offshore rocks have yielded significant numbers of migratory breeder remains from the Late Period (Monterey, Spanish Flat, Shelter Cove), but settlement systems in these areas show a decided focus on the interior. In such cases, a minimal human presence during certain sea- sons facilitated a rebound in migratory sea mammal populations on the mainland. These locations further speak to limitations of coastal resources in areas without offshore rocks and islands, where intensified economies could only develop with a focus on terrestrial resources.

The Channel Islands also exhibit diachronic patterns different from the rest of the California and Oregon open coasts, as migratory breeder populations rebounded during the Late Period, following what had previously been a steady decline. Occupational hiatuses and/or temporarily depressed human populations (Arnold 1992b:134) caused by severe drought during the interval known as the Little Climatic Optimum or Medieval Warm Period (A.D. 1000-1300; Stine 1994) apparently allowed for a revitalization of fur seal and sea lion rookeries on the islands.

From the five alternative perspectives outlined in the beginning of this paper, we submit that a model of intensification and overexploitation provides the most coherent explanations for the broad-scale diachronic patterns in the marine zooarchaeological data from Oregon and California. The progression from exploitation of readily exploitable taxa to more elusive taxa, coincident with the development of more sophisticated weaponry and watercraft suggests that technological innovations arose from necessity, not from historic happenstance. Frequencies of marine mammal remains generally show linear progression through time, suggesting minimal influence from sea water temperature change. Sophisticated watercraft were developed before the environmental oscillations of the Medieval Warm Period, suggesting they were an outgrowth of thousands of years of slowly intensifying subsistence and overexploitation. Some form of advanced socio-political organization must have been in place prior to the appearance of craft-specialization on the 
Islands, which is contrary to the neoMarxist model advocated by Arnold (1991, 1992a, 1992b). Significant diachronic decline in the most optimal taxa is further contrary to the resource enhancement model proposed by Lyman in this volume. Because of their need to breed on land, their vulnerability to terrestrial predation when congregated in breeding colonies, and their occupation of migration corridors several thousands of kilometers in length, migratory pinnipeds were inordinately susceptible to a tragedy of the commons.

Lyman's challenge to our interpretations has brought nothing but the most positive results. His questioning has forced us to examine our data more critically, which has ultimately led to more thoughtful interpretation. We also strongly agree with Lyman's contention that we will only make limited progress in the study of maritime hunting adaptations until robust sets of age/sex data are available. The major point of divergence between ourselves and Lyman on this issue has been our willingness to develop an explanatory model with currently available data, despite a general absence of age/sex information. We all agree that large, well-analyzed collections are ultimately needed to reject any of the alternative hypotheses. Collections with significant numbers of identified specimens are particularly uncommon from the southern California coast, and age/sex data are nearly non-existent. Given a longstanding emphasis on small-scale data recovery strategies, particularly the exclusive use of column samples, and a recent emphasis on even smaller screen size $\left(1 / 16^{\prime \prime}\right.$ which is necessary for some types of questions [see Erlandson 1994]), the large data gap which exists along the south coast is likely to persist well into the future.

\section{NOTE}

We take this opportunity to correct an error in our 1992 paper. On page 384 we incorrectly reported that
Colten ascribed low logistical mobility to the Early Period in the Santa Barbara Channel, when in fact he argues for low residential mobility during that time.

\section{REFERENCES CITED}

Arnold, J. E.

1991 Transformation of a regional economy: Sociopolitical evolution and production of valuables in southern California, Antiquity 65:953-962.

1992a Complex hunter-gatherer-fishers of prehistoric California: Chiefs, specialists, and maritime adaptations of the Channel Islands, American Antiguity 57:60-84.

$1992 \mathrm{~b}$ Cultural disruption and the political economy in Channel Islands prehistory. In Essays on the prehistory of maritime California, edited by T. L. Jones, pp. 129-144. Center for Archaeological Research at Davis, Publication No. 10, University of California, Davis.

Arnold, J. E., and B. N. Tissot

1993 Measurement of significant marine paleotemperature variation using black abalone shells from prehistoric middens, Quaternary Research 39:390-394.

Baker, J. D.

1989 Aquatic copulation in the northern fur seal, Callorhinus ursinus, Northwestern Naturalist 70:33-36.

Bartholomew, G. A.

1970 A model for the evolution of pinniped polygyny, Evolution 24:546-559.

Basgall, M. E.

1987 Resource intensification among huntergatherers: Acorn economies in prehistoric California, Research in Economic Anthropology 9:21-52.

Bleitz-Sanburg, D.

1987 The changing exploitation of mammalian and avian food resources at SNI-11, San Nicholas Island, California. Unpublished Master's thesis, University of California, Los Angeles.

Bonnell, M. L., Le Boeuf, B. J., Pierson, M. O., Dettman, D. H., and G. D. Farrens

1978 Marine mammals and seabird surveys of the southern California bight area, vol. III. Contract Report AA530-CT7-36 from the Bureau of Land Management. Ms on file, Department of Biology, University of California, Santa Cruz.

Bonnot, P.

1928 The sea lions of California, California Fish and Game 14:1-16.

Chartkoff, J. L., and K. K. Chartkoff

1984 The archaeology of California. Stanford University Press, Stanford. 
Colten, R. H.

1992 Preliminary analysis of faunal remains from four sites on Santa Cruz Island, Proceedings of the Society for California Archaeology 5:247268.

1993 Prehistoric subsistence, specialization, and economy in a southern California chiefdom. Unpublished Ph.D. dissertation, Institute of Archaeology, University of California, Los Angeles.

Davenport, D., J. R. Johnson, and J. Timbrook

1993 The Chumash and the swordfish, Antiquity 67:257-272.

Dietz, S. A., W. R. Hildebrandt, and T. Jones

1988 Archaeological investigations at Elkhorn Slough: CA-MNT-229, a Middle Period site on the central California coast, Papers in Northern California Anthropology 3, Berkeley.

Dietz, S. A., and T. L. Jackson

1981 Report of archaeological excavations at nineteen archaeological sites for the stage 1 Pacific GroveMonterey consolidation project of the regional sewage system. Archaeological Consulting and Research Services. Submitted to Engineering-Science, Berkeley. Copies available from Archaeological Consulting and Research Services, Santa Cruz.

Elsasser, A. B.

1978 Development of regional prehistoric cultures. In Handbook of North American Indians Volume 8 California, edited by R. F. Heizer, pp. 37-57. Smithsonian Institution, Washington, D.C.

Elsasser, A. B., and R. F. Heizer

1966 Excavation of two northwestern California coastal sites, University of California Archaeological Survey Reports 67:1-149.

Engelbrecht, W., and C. K. Seyfert

1994 Paleoindian watercraft: Evidence and implications, North American Archaeologist, 15:221-234.

Erlandson, J. M.

1994 Early hunter-gatherers of the California coast. Plenum Press, New York.

Erlandson, J. M., and R. H. Colten

1991 Hunter-gatherers of early holocene coastal California. Perspectives in California Archaeology No. 1, Institute of Archaeology, University of California, Los Angeles.

Fiscus, C. H

1978 Northern fur seal. In Marine mammals, edited by D. Haley, pp. 153-159. Pacific Search Press, Seattle.

Fladmark, K. R.

1979 Routes: Alternative Migration Corridors for Early Man in North America, American Antiquity 44:55-69.
Frederickson, D. A.

1984 The north coastal region. In California Archaeology, edited by M. J. Moratto, pp. 471528. AcademiPress, San Francisco.

Gard, H. A.

1992 Resource distribution and prehistoric utilization of southern Oregon's coastal islands, Northwest Science 66:207-217.

Gentry, R. L.

1981 Northern fur seal Callorhinus ursinus [Linnaeus, 1758]. In Handbook of Marine Mammals Volume 1, edited by S. H. Ridgeway and R. J. Harrison, pp. 143-210. Academic Press, London.

Gerber, J. L. (Editor)

1993 Archaeological investigations at CA-SBA-1731: A Middle-to-Late Period site on the Santa Barbara Channel. Dames and Moore, Santa Barbara. Prepared for Exxon Company USA. Copies available from Dames and Moore.

Glassow, M.

1992 The relative dietary importance of marine foods through time in western Santa Barbara County. In Essays on the prehistory of maritime California, edited by T. L. Jones, pp. 115-128. Center for Archaeological Research at Davis Publication No. 10, University of California, Davis.

1993 Changes in subsistence on marine resources through 7,000 years of prehistory on Santa Cruz Island. In Archaeology on the northern Channel Islands of California, edited by M. A. Glassow. Archives of California Prehistory No. 34, Salinas.

Glassow, M., L. Wilcoxon, and J. Erlandson

1988 Cultural and environmental change during the Early Period of Santa Barbara channel prehistory. In The archaeology of prehistoric coastlines, edited by G. Bailey and J. Parkington, pp. 64-77. Cambridge Univ. Press, New York.

Goldberg, C.

1989 Column sample analysis and dietary reconstruction, Anthropology U.C.L.A. 16:24-34.

Gould, R. A.

1966 Archaeology of the Point Saint George site and Tolowa prehistory, University of California Publications in Anthropology 4.

1975 Ecology and adaptive response among the Tolowa Indians of northwestern California, Journal of California Anthropology 2:148-180.

Graumlich, L. J.

1993 A 1000-year record of temperature and precipitation in the Sierra Nevada, Quaternary Research 39:249-255.

Heizer, R. F.

1951 A prehistoric Yurok ceremonial site (HUM- 
174), University of California Archaeological Survey Reports 11:1-4.

Hildebrandt, W. R.

1981 Native hunting adaptations on the north coast of Califormia. Unpublished Ph.D. dissertation, Department of Anthropology, University of California, Davis.

1984a Late Period hunting adaptations on the north coast of California. Journal of California and Great Basin Anthropology 6:189-206.

1984b Archaeological presence of the northern fur seal (Callorhinus ursinus) along the coast of northern California, The Murrelet 65:28-29.

Hildebrandt, W. R., and T. L. Jones

1992 Evolution of marine mammal hunting: A view from the California and Oregon coasts, Journal of Anthropological Archaeology 11:360-401.

Jobson, R. W., and W. R. Hildebrandt

1980 The distribution of ocean-going canoes on the north coast of California, Journal of California and Great Basin Anthropology 2:165174.

Jones, T. L.

1991 Marine-resource value and the priority of coastal settlement: A California perspective, American Antiguity 56:419-443.

1992 Settlement trends along the California coast. In Essays on the Prehistory of Maritime California, edited by T. L. Jones, pp. 1-37. Center for Archaeological Research at Davis, Publication No. 10. University of California, Davis.

1995 Transitions in prehistoric diet, mobility, exchange, and social organization along California's Big Sur coast. Unpublished Ph.D. dissertation, Department of Anthropology, University of California, Davis.

Kenyon, K. W.

1969 The sea otter in the eastern Pacific Ocean. U.S. Department of the Interior, Bureau of Sport Fisheries and Wildlife, Washington, D.C.

1978 Sea otter. In Marine mammals of the eastern north Pacific rim and arctic waters, edited by D. Haley, pp. 226-235. Pacific Search Press, Seattle.

1982 Sea otter. In Wild mammals of North America, edited by J. A. Chapman and G. A. Feldmamer, pp. 704-710. John Hopkins Univ. Press, Baltimore.

King, C. D.

1990 The evolution of Chumash society: A comparative study of artifacts used in social system maintenance in the Santa Barbara Channel region before A.D. 1804. Garland Publishing, New York.
King, J. E.

1983 Seals of the world. Cornell Univ. Press, Ithaca.

King, L.

1982 Medea Creek cemetery: Late inland Chumash patterns of social organization, exchange, and warfare. Unpublished Ph.D. dissertation, Department of Anthropology, University of California, Los Angeles.

Kroeber, A. L.

1925 Handbook of the Indians of California. Bureau of American Ethnology Bulletin 78. Washington, D.C.

Larson, D., J. R. Johnson, J. Michaelson

1993 Missionization among the coastal Chumash of central California: A study of risk minimization strategies, American Anthropologist 96:263-299.

Le Boeuf, B. J.

1981 Mammals. In The Natural History of Año Nuevo, edited by B. J. Le Boeuf and S. Kaza, pp. 287-326. Boxwood Press, Pacific Grove, CA.

Le Boeuf, B. J., and M. L. Bonnell

1980 Pinnipeds in the California islands: Abundance and distribution. In The California islands: Proceedings of a multi-disciplinary symposium, edited by D. M. Power, pp. 475493. Santa Barbara Museum of Natural History.

Levulett, V. A.

1985 The prehistory of southwestern Humboldt County: A study of coastal archaeological sites in the King Range National Conservation Area. Unpublished Ph.D. dissertation, Department of Anthropology, University of California, Davis, CA.

Levulett, V. A., and W. R. Hildebrandt

1987 The King Range archaeological project: Results of the 1984 field season. Report on file, Bureau of Land Management, Ukiah, CA.

Lightfoot, K. G.

1993 Long-term developments in complex hunter-gatherer societies: recent perspectives from the Pacific coast of North America, Journal of Archaeological Research 1:167201.

Loughlin, T. R., M. A. Perez, and R. L. Merrick

1987 Eumetopias jubatus, Mammalian Species 283: $1-7$.

Love, J. A.

1990 Sea otters. Whittet Books, London.

Lyman, R. L.

1989 Seal and sea lion hunting: A zooarchaeological study from the southern northwest coast of North America, Journal of Anthropological Archaeology 8:68-99. 
1991a Prehistory of the Oregon coast. Academic Press, San Diego.

$1991 \mathrm{~b}$ Subsistence change and pinniped hunting. In Human predators and prey mortality, edited by M. C. Stiner, pp. 187-199. Westview Press, Boulder, Colorado.

Lyon, G. M.

1937 Pinnipeds and a sea otter from the Point Mugu shellmound of California, University of California Los Angeles Publications in Biological Sciences 1:133-255.

Martz, P.

1992 Status distinctions reflected in Chumash mortuary populations in the Santa Monica Mountains region. In Essays on the prehistory of maritime California, edited by T. L. Jones, pp. 145-156. Center for Archaeological Research at Davis, Publication No. 10. University of California, Davis.

Mate, B. R.

1975 Annual migrations of the sea lions Eumetopias jubatus and Zalophus californianus along the Oregon coast, Rapports et Proces-Verbaux 169:455-461

Milburn, J. W., D. A. Fredrickson, M. Dreiss, L. Demichael, and W. Van Dusen

1979 A preliminary report on the archaeology of $\mathrm{CA}$ HUM-129. Report on file, Anthropological Studies Center, Sonoma State University, Rohnert Park, CA.

Peterson, R. S., and G. A. Bartholomew

1967 The natural history and behavior of the California sea lion, American Society of Mammalogists Special Publication No. 1.

Pisias, N. G.

1979 Model for paleoceanographic reconstructions of the California current during the last 8000 years, Quaternary Research 11:373386.

Raab, L. M.

1994 The dead at Calleguas Creek: A study of punctuated cultural evolution during the middle-late period transition in southern California. Center for Public Archaeology, California State University, Northridge. Prepared for Envi- ronmental Division, Naval Air weapons Station, Point Mugu, California.

Raab, L. M., K. Bradford, J. C. Porcasi, and W. J. Howard

1995 Return to Little Harbor, Santa Catalina Island, California: A critique of the marine paleotemperature model, American Antiquity, in press.

Raab, L. M., A. Yatsco, and K. Bradford

1994 Advances in southern Channel Island archaeology: 1983-1993. Paper presented at the 4th California Island Symposium, Santa Barbara.

Salls, R.

1992 Prehistoric subsistence change on California's Channel Islands: Environmental or cultural? In Essays on the prehistory of maritime California, edited by T. L. Jones, pp. 157-172. Center for Archaeological Research at Davis, Publication No. 10. University of California, Davis.

Scammon, C. $M$.

1874 The marine mammals of the northwest coast of North America. John Carmany and Sons, San Francisco, CA.

Scheffer, V. B.

1958 Seals, sea lion, and walruses. Stanford University Press, Palo Alto.

Schwaderer, R.

1992 Archaeological test excavation at the Duncans Point Cave, CA-SON-348/H. In Essays on the prehistory of maritime California, edited by T. L. Jones, pp. 55-71. Center for Archaeological Research at Davis, Publication No. 10. University of California, Davis.

Stine, $\mathrm{S}$.

1994 Extreme and persistent drought in California and Patagonia during mediaeval time, Nature 369:546-549.

Walker, P. L., M. J. DeNiro, and P. Lambert

1989 The effects of European contact on the health of Alta California Indians. In Columbian consequences, edited by David Hurst Thomas, Vol. I, pp. 349-364. Smithsonian Institution, Washington, DC. 